\title{
Identification of a New Industrial Area Based on a Macro-Level Analysis - a Case of Bokaro District, Jharkhand, India
}

\author{
Bimal Chandra Roy, Satyaki Sarkar, Rajan Chandra Sinha, Indraneel Srivastava
}

\begin{abstract}
Locating a new industrial area involves a strategic decision that covers several criteria with consideration for socio-economic benefits and environmental sustainability alongwith technical, and political issues. These different criteria are described using a number of indicators in terms of quantity and quality with some possible uncertainty. Decision making thus requires appropriate tools for data collection, analysis and knowledge management to address this multidisciplinary situation. This paper tries to find out the comprehensive method for industrial site location, a sustainable approach for finding the most suitable solution. Identifying the location determinants and site suitability models used for allocating an industrial site is observed to be an essential aspect of siting of industry, as such; level of decision making is dependent on predefined constraints. Multicriteria decision making method (M.C.D.M) seems to be a consistent and efficient solution which forms the basis for locating multiple sites for industrial activity in any delineated area.
\end{abstract}

Keywords: Land Appropriation, Location Determinants, Site Suitability, Predefined Constraints, Multicriteria Decision Making (M.C.D.M)

\section{INTRODUCTION}

The basic conventional methods of placing the industry closer to settlement and agglomeration were implemented with an intention of boosting the economic growth by providing greater employment opportunity to the area. The need of revitalization and rejuvenation of urban life lead to an ideology that development and urban planning should go hand in hand. The main pull factor for locating an industry has always been the availability of raw materials needed for production and processing of goods in order to achieve desirable outputs. However it is witnessed that there are some other significant and momentous factors which are to be considered before finalising the location of the site for the industry. In the last $20^{\text {th }}$ Century, Mankind saw tremendous growth in technology advances in Industrial and Production Sector with exponential use of natural resources and environment to meet up the ever-growing needs and demands.

Revised Manuscript Received on December 30, 2019.

* Correspondence Author

Bimal Chandra Roy*, Assistant Professor, Department of Architecture, Birla Institute of Technology, Mesra, Ranchi 835215 (Jharkhand) India. E-mail:bimalcroy@gmail.com

Satyaki Sarkar, Associate Professor, Department of Architecture, Birla Institute of Technology, Mesra, Ranchi 835215 (Jharkhand) India. E-mail:satyakisarkar2002@gmail.com

Rajan Chandra Sinha, Assistant Profesor Department of Architecture, Birla Institute of Technology, Mesra, Ranchi 835215 (Jharkhand) India. E-mail:rajanchandrasinha@gmail.com

Indraneel Srivastava, Urban Planner, HEC, Ranchi 834001 (Jharkhand) India. E-mail:indraneelsrivastava@gmail.com

(C) The Authors. Published by Blue Eyes Intelligence Engineering and Sciences Publication (BEIESP). This is an open access article under the CC BY-NC-ND license (http://creativecommons.org/licenses/by-nc-nd/4.0/)
At global scale, Mining and Manufacturing sector predominates most of industries all around the globe. Manufacturing sector became an integral sector involving production and labour inside developed countries over the Industrial Revolution, upsetting preceding mercantile in addition to feudal establishments. This happened through many successive speedy advances inside technology, like the production steel and coal. after the Industrial Revolution, perhaps a third of world's economic output comes from manufacturing companies. The mining industry considered key for the development associated with civilization, which has been depend on the iron and bronze in the earlier time. Mining operation, which involves extraction Various minerals from the earth crust, comes in second only to agriculture since the world's oldest and crucial activity. Within the last few years, mining industries are developing quickly. And ideal sites intended for new plants are stalled due to the development associated with countryside (rural areas) and also the rising worry over environmentally friendly and legalities. The challenge is to identify a place for the modern industry closer to place associated with mining to cut back the item cost. Therefore, selecting the place (site selection) for the new energy plant must be done cautiously and take into many factors under consideration. Although Industries have revolutionized the economy and living standards of human beings over time, Industry siting on the land has a negative impact on overall living environment, soil structure and local ecosystem. Land degradation, depletion of fauna and flora and pollution are some global issues which are directly related to industrial land siting.

Industrial Revolution that took place in $18^{\text {th }}$ Century lead to Modernization of Trends in Urban Planning. There was advancement in Transportation, Public Utilities etc. Industrial Site Selection process was pioneered in the $18^{\text {th }}$ Century England with the introduction of Factory towns/Mill towns and garden city as a planning practice.

a. Every amenity of Urban Life was sacrificed to the requirements of Industries.

b. Railroads and Ships joined the factories and waterfronts became the industrial core of the city

Factory Town Concept failed because of increase in even working-class population, problems of public health and safety, environmental issues, no land use standards for future development. Garden City Concept failed because of defined railway line and green belt buffer between Industries and City Centre, there was more influx of people \& factories and increasing urban structure of the city in all directions. 


\section{Identification of a New Industrial Area Based on a Macro-Level Analysis - a Case of Bokaro District, Jharkhand, India}

From physical planning point of view process of selection of site and land use is defined in terms of zoning. Industrial Zoning is the process of dividing land into zones in which various industrial setup may be permitted or prohibited. The type of zone determines whether planning permission for a given development is granted. Zoning may indicate the size and dimensions of the plotted land as well as the form and scale of factories. Perspective Plan provides an overall vision for preparation of detail plan of land use and various development prospects in the local area. It acts as a guide for local governing body. Industrial Location Plan, Resource Mapping are a part of Perspective plan which contributes to overall Regional Development. India is a country gifted with a great variety and extent of natural resources, labour force, mineral deposits, agriculture. Agriculture and Manufacturing sector are some of the largest industries contributing to India's booming economic growth. While Agriculture and Manufacturing industries are spread all over India, Mining sector is confined to areas with Mineral Deposits. Eastern India is rich in mineral ores whereas Western India has rich deposits of Lignite resources. A mineral based industry largely affects the surrounding living system since the environment is disturbed by excavation, mining and processing of minerals. Manufacturing Industry on the other hand requires continuous inflow of raw materials and prefers close proximity with its needed resources. Hence to identify a Industrial Zone, a number of decision making criteria which are favorable for industries should be considered keeping in mind minimal possible use of physical resources and minimum possible impact on ecosystem and environment. Jharkhand is a State in eastern part of India which contributes to $37 \%$ of country's total raw mineral deposits. It has been a targeted destination for various industrial power houses from state owned to private conglomerate such as TATA, NTPC, SAIL, CIL etc. in the past. Being a rich state in natural resources, mineral deposits, agricultural land, Jharkhand has huge potential for Industrial Establishment in the future.

"First ever large-scale Site Selection Practices at Regional level for industrial establishment in Jharkhand was witnessed during early $20^{\text {th }}$ Century when TATA Sons, a National level conglomerate with the help of geologist Charles Page Perin from Pittsburgh, US identified suitable site for siting up India's first steel plant (TISCO) in East Singhbhum Area which had extensive varieties of Minerals \& Resources ideal for steel-based industry establishment." Many new Industrial Sites were identified in Jharkhand for Mining, Mineral Processing, Finishing Products, Manufacturing in 1960-1980s. New industrial site identification process starts with defining many establishing criteria put forward by investors and stakeholders.

\section{A. NEED FOR THE STUDY}

a. To encourage investments in the study area by locating best industrial site with minimal impact on surroundings for future industrial development.

b. Empowering entrepreneurs, promoters, Industrial decision makers by creating safe, supportive environments that foster collective prosperity, innovation and adaptability to local conditions.

\section{DELINEATION OF AREA FOR SITING OF INDUSTRIES}

Delineation of the study area is the first step for preparing the regional development plan. Ministry of Environment and Forests, Government of India has already proposed rules and regulations in which criteria has been defined for Areas to be avoided for Siting of Industries. Application of these criteria will lead to delineation of land which is available in the study

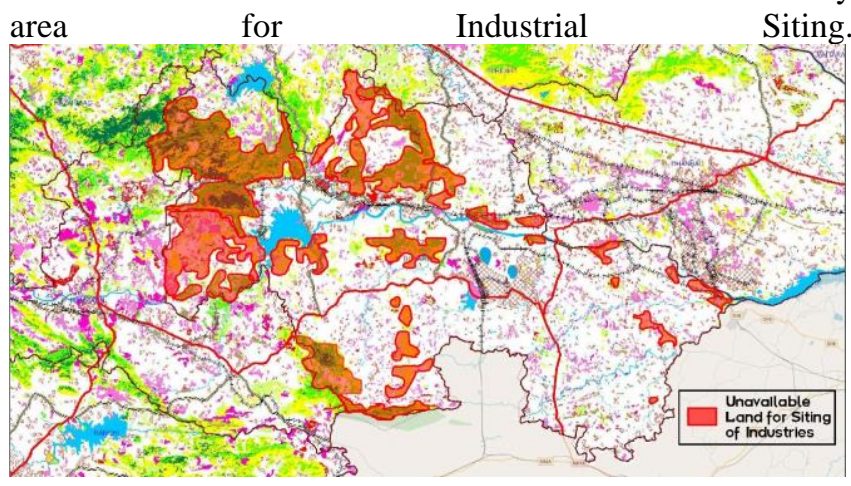

Figure 1 - Unavailable land for siting of industries after considering the restrictions on forest land: (forest conservation act, 1980). - reserve, protected and communal forests, restrictions on prime agricultural land: areas characterized by extensive agriculture landuse, agriculture production areas, command areas of irrigation projects

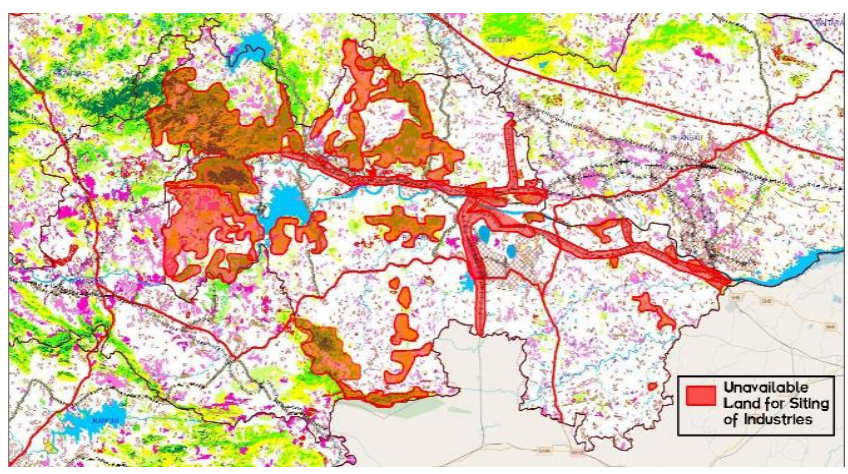

Figure 2 - Right-of-way of the railways- a railway property adjacent to the site, is a, restriction on industrial development - at least $800 \mathrm{~m}$ - 1500m from no development zone.

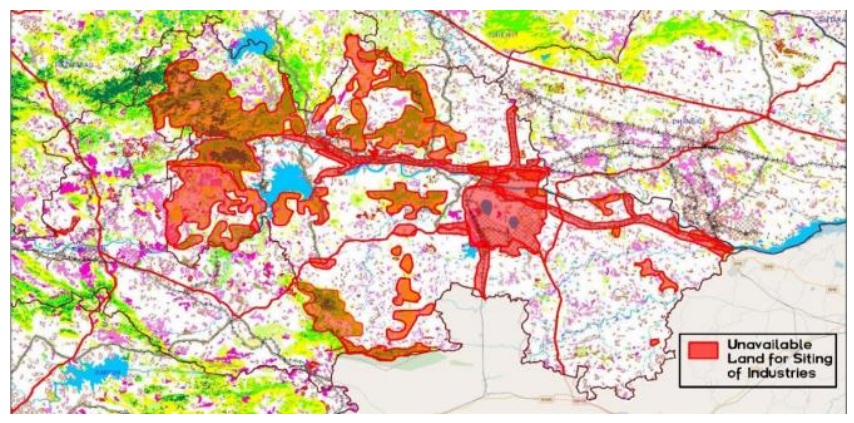

Figure 3 - Restrictions on siting near major settlements any major settlement notified limit is within $20 \mathrm{~km}$, the spatial direction of growth of the settlement $(5-10 \mathrm{~km}$ radius), restrictions on siting near airport areas - the heights of the buildings should be regulated and no objection certificate is required from Airport Authority of India.

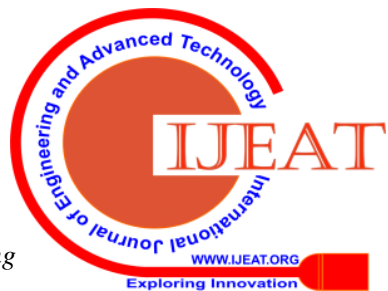




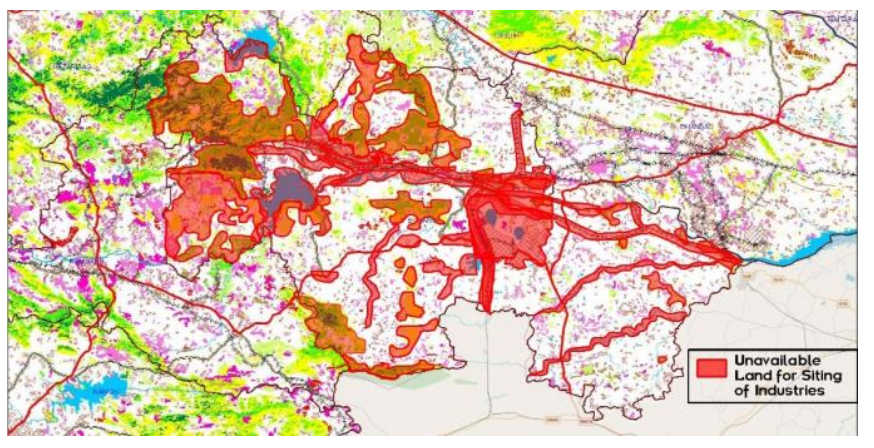

Figure 4 - Restriction on industrial siting on marshy, erodible land - site should be at least $1-3 \mathrm{~km}$ from highly permeable soil. It should be at least $0.5 \mathrm{~km}$ from flood plain affected by dam and present water bodies.

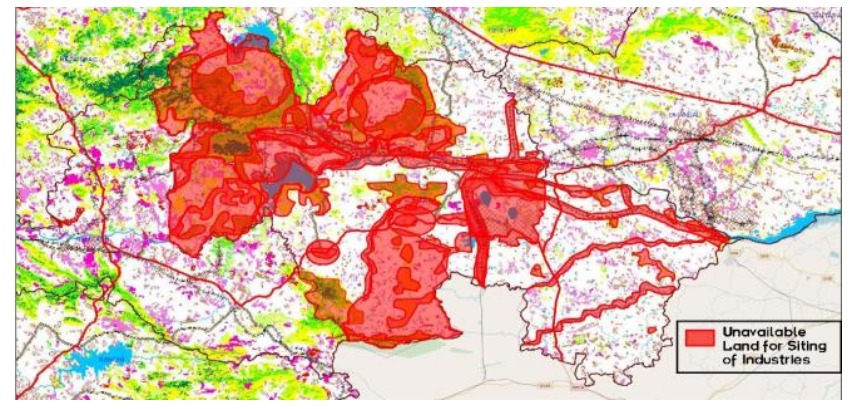

Figure 5 - All identified areas around protected areas and wildlife corridors around $25 \mathrm{~km}$ radius are to be declared as ecologically fragile under the Environment (Protection) Act

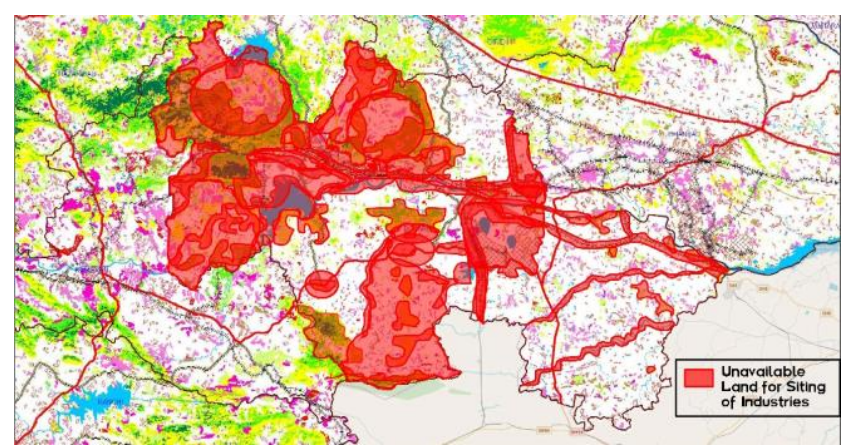

Figure 6 - Restrictions in hazardous zones - Areas susceptible to man-made and natural disasters include areas with high-risks of earthquakes, floods, tsunami, , mining excavation sites, mining \& quarry land, mineral dumping land etc.

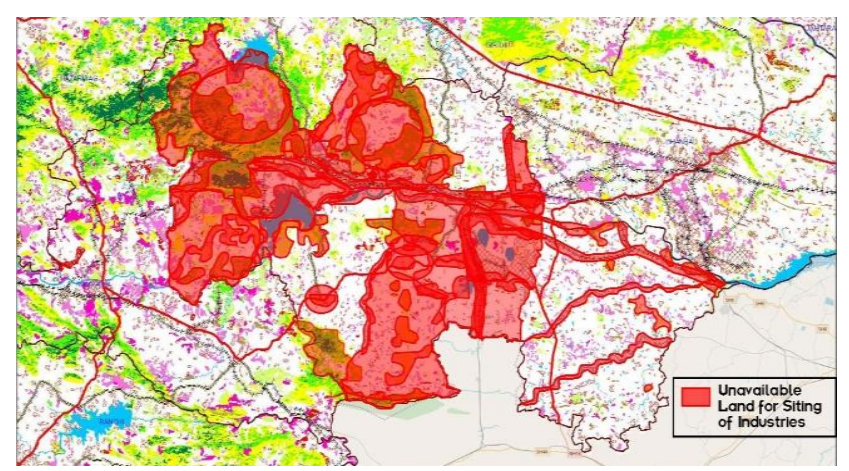

Figure 7 - Restrictions as per CPCB - Environmental Atlas for Bokaro District prepared by Bokaro (EIA) Environmental Impact Assessment Authority for Air and Water Polluting Industries.

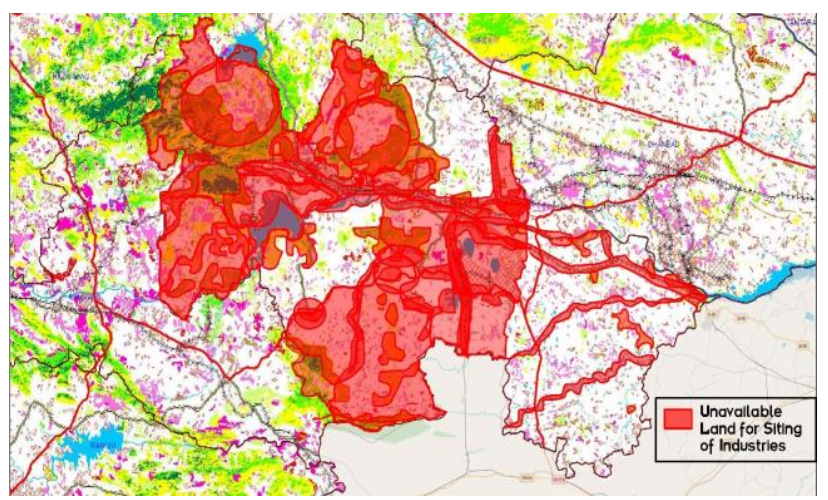

Figure 8 - Restriction on Human Footprint - Areas excluding urban areas with Global Human Footprint Rating between 11-20 (5-15 pph) Areas with Major share of population (at least $80 \%$ ) of the area is dependent on agriculture as the major source of livelihood.

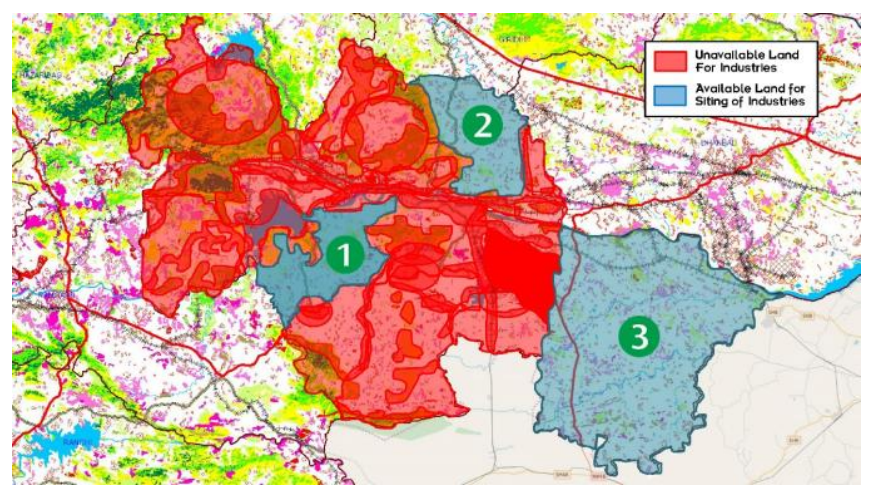

Figure 9 - The final delineated study area showing the available land for siting of industries.

Based on application of guidelines prescribed by the Government of India, The land has been subdivided based on elimination of unavailable land for siting to identify the present available land for siting of industry. Three (3) land parcel at district level can be identified. The profile of these land parcels at district level are as follows:

1) Area in Peterbar Subdistrict (206.75 sq. km) - Located near newly formed Ramgarh District. This area is connected by Ranchi - Dhanbad Express highway. It has Tenughat Reservoir and Garga Dam in nearby proximity which is the only water source is the surrounding areas

2) Area in Chandrapura Subdistrict (191.81 sq. km) Located near the coal capital of India Dhanbad. This area is in proximity to GT Road and Delhi Kolkata Rail Corridor. Damodar River crosses this area which is water source in the area.

3) Area in Chandankiyari Subdistrict (485.35 sq. km) Located in the eastern part of Bokaro District. This area is located near Purulia District. It has NH18 and centrally located SH9 Raghunathpur - Bokaro Road which connects to Raghunathpur, Purulia and Burnpur areas of West Bengal. The area has tributary of Damodar River which is the major water source. Small rural areas are located on the banks of these rivers. 


\section{Identification of a New Industrial Area Based on a Macro-Level Analysis - a Case of Bokaro District, Jharkhand, India}

\section{RESEARCH METHODS}

This method evaluates the multiple criteria which are conflicting in decision making. Since siting an industrial location is a very complex socio economic problem, this method facilitates groups or individual decision maker by assigning a weight to each criteria under consideration.

The desired criteria were identified based on a primary survey for industrial decision makers conducted in the study area. The targeted population included Directors, General Managers, Project Managers of various established industries in the area

\section{A. Multi - CRIteria DECISION METHOD}

Industrial site selection criteria identified based on primary survey of industrial decision makers are-

a. Availability of Resources (JSAC Resources Plan)

b. Landcover and Landuse (Existing Landcover Map) c. Type of Wasteland (JSAC Wasteland Layer)

d. Proximity to Transport Corridor (JSAC Transport) e. Land Pricing (Govt of Jharkhand)

f. Terrain, Slope, Topography (JSAC Slope Layer)

g. Environmental Attributes (Bokaro Environmental Atlas)

h. River Proximity (JSAC Water Bodies Layer)

Questionnaire was designed into yield comparison matrix from total sample collected. The following was aspects were surveyed from the participants: -

A. 1. Relative comparison between two criteria at a time in order to yield a matrix.

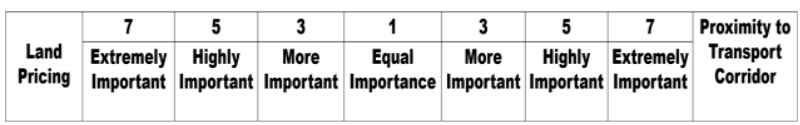

A. 2. Ranking which is to be given to individual criteria under the Scheme Site Selection Priorities of Decision Makers 3) Personal Opinion and Suggestion about various Infrastructure Priorities in a New Industrial area or a new industrial landuse distribution/arrangement.

\section{B. CALCULATION OF COMPOSITE SUITABILITY FUNCTION (S)}

B.1 For individual criteria maps - The Criteria maps depicts suitability scale after consultation from MCDA and primary survey of Industrial Decision Makers. The Suitability Function for each is the product of adjusted weight (w) calculated for that individual criteria, the assumed suitability scale (x) from highly suitable to least suitable areas, the reclassified thematic layer (c) processed from raw data obtained.

$$
S=\sum w_{i} x_{i} \times \prod c_{j}
$$

B.2 For Final Suitability Map - After generation of criteria maps the summation of reclassified thematic layer (from Overlay analysis) is multiplied by the summation of adjusted weights (w) and assumed suitability scale.

\section{B .3 Calculations to compare the criteria}

Defining Multi - Criteria Problem, Decomposing the Problem into hierarchy of criteria for 8x8 Matrix, Calculation of Priority Eigen Vector Normalization of Values - Finding Consistency Index and Consistency Ratio, Calculation of Weights for Criteria based on Priority Eigen Vector, Defining Suitability Score and Scale Calculation of Suitability Function

No of Comparisons $=28$

Based on the survey, individual criteria are compared and the sum of each column is calculated in order to normalise the values in the next step.

Table 1 - Relative weights for various criteria

\begin{tabular}{|c|c|c|c|c|c|c|c|c|}
\hline CRITERIAS & 1 & 2 & 3 & 4 & 5 & 6 & 7 & 8 \\
\hline 1 & 1 & 1 & 3 & 1 & $1 / 5$ & 5 & $1 / 3$ & 5 \\
\hline 2 & 1 & 1 & 5 & $1 / 5$ & $1 / 5$ & 1 & 3 & 5 \\
\hline 3 & $1 / 3$ & $1 / 5$ & 1 & $1 / 3$ & $1 / 3$ & 1 & 3 & 3 \\
\hline 4 & 1 & 5 & 3 & 1 & 1 & 3 & 3 & 5 \\
\hline 5 & 5 & 5 & 3 & 1 & 1 & 7 & 3 & 3 \\
\hline 6 & $1 / 5$ & 1 & 1 & $1 / 3$ & $1 / 7$ & 1 & $1 / 3$ & 3 \\
\hline 7 & 3 & $1 / 3$ & $1 / 3$ & $1 / 3$ & $1 / 3$ & 3 & 1 & 7 \\
\hline 8 & $1 / 5$ & $1 / 5$ & $1 / 3$ & $1 / 5$ & $1 / 3$ & $1 / 3$ & $1 / 7$ & 1 \\
\hline
\end{tabular}

\begin{tabular}{|l|l|l|l|l|l|l|l|}
\hline 11.73 & 13.73 & 16.66 & 4.54 & 3.54 & 21.33 & 13.80 & 32 \\
\hline
\end{tabular}

Each value of each cell is divided by the column sum to obtain a comparison matrix between the criteria.

Table 2 - Adjusted relative weights for various criteria

\begin{tabular}{|c|c|c|c|c|c|c|c|c|c|}
\hline CRITERIAS & 1 & 2 & 3 & 4 & 5 & 6 & 7 & 8 & $\begin{array}{c}\text { ROW } \\
\text { suM/s }\end{array}$ \\
\hline 1 & 0.085 & 0.072 & 0.18 & 0.22 & 0.056 & 0.23 & 0.024 & 0.15 & 0.128 \\
\hline 2 & 0.085 & 0.072 & 0.3 & 0.044 & 0.056 & 0.046 & 0.21 & 0.15 & 0.122 \\
\hline 3 & 0.028 & 0.014 & 0.06 & 0.073 & 0.094 & 0.046 & 0.21 & 0.093 & 0.078 \\
\hline 4 & 0.085 & 0.36 & 0.18 & 0.22 & 0.028 & 0.14 & 0.21 & 0.15 & 0.205 \\
\hline 5 & 0.42 & 0.36 & 0.18 & 0.22 & 0.028 & 0.32 & 0.21 & 0.093 & 0.263 \\
\hline 6 & 0.17 & 0.072 & 0.06 & 0.073 & 0.04 & 0.046 & 0.024 & 0.093 & 0.053 \\
\hline 7 & 0.25 & 0.024 & 0.02 & 0.073 & 0.094 & 0.14 & 0.072 & 0.218 & 0.112 \\
\hline 8 & 0.017 & 0.014 & 0.02 & 0.044 & 0.094 & 0.015 & 0.0103 & 0.031 & 0.038 \\
\hline
\end{tabular}

The horizontal average of these cell results in a Priority Eigen Vector which describes the priority given by decision makers of one criteria over the other. With the help of the calculated priority vector, adjusted weights can be calculated and respective to each criterion can be allocated.

Table 3 - Adjusted relative weights for various criteria obtained from calculated Eigen Vector

\begin{tabular}{|c|lc|}
\hline $\begin{array}{c}\text { Availability of Resources } \\
\text { and Raw Materials (1) }\end{array}$ & ADJUSTED WEIGHT $=\frac{12.28 \%}{20.5 \%+26.3 \%}=0.26239$ & $3 \mathrm{rd}$ \\
\hline Landcover and Landuse (2) & ADJUSTED WEIGHT $=\frac{12.22 \%}{20.5 \%+26.3 \%}=0.26111$ & 4 th \\
\hline $\begin{array}{c}\text { Availability of } \\
\text { Waste/Barren Land (3) }\end{array}$ & ADJUSTED WEIGHT $=\frac{7.8 \%}{20.5 \%+26.3 \%}=0.16667$ & 6 th \\
\hline $\begin{array}{c}\text { Proximity to Transport } \\
\text { Corridor (Rai/Roads) (4) }\end{array}$ & ADJUSTED WEIGHT $=\frac{20.5 \%}{20.5 \%+26.3 \%}=0.43803$ & nd \\
\hline $\begin{array}{c}\text { Land Pricing, Valuation (5) } \\
\text { Terrain, Slope, Topography } \\
(6)\end{array}$ & ADJUSTED WEIGHT $=\frac{26.5 \%}{20.5 \%+26.3 \%}=0.56623$ & 7 th \\
\hline $\begin{array}{c}\text { Environmental Attributes } \\
(7)\end{array}$ & ADJUSTED WEIGHT $=\frac{5.3 \%}{20.5 \%+26.3 \%}=0.11324$ & 5 th \\
\hline $\begin{array}{c}\text { Geomorphology, Geology } \\
\text { \& River Proximity (8) }\end{array}$ & ADJUSTED WEIGHT $=\frac{3.8 \%}{20.5 \%+26.3 \%}=0.08119$ \\
\hline
\end{tabular}

\section{RECLASSIFICATION OF SPATIAL LAYERS}

Reclassification is an effective tool used in GIS for creating a categorical attributes in a dataset by classifying various features based on existing attributes.

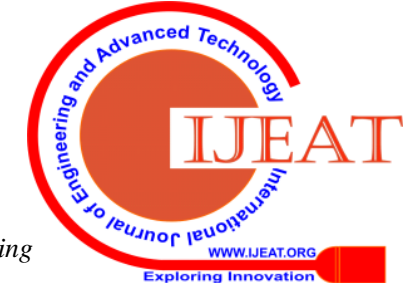


Way to interpret an attribute to a map is done through GIS using two methods: -

Grid Overlay Method - It is method in which the attributes on the map are overlayed in Grid Iron Pattern. It is a useful method in order to find change the values of the map attributes. It is usually used for small area which are less than 50 sq. km, interpretation of area.

Polyline Overlay Method - It is a method in which the polyline boundary of spatial features is reclassified and interpretation. In this research, Polyline Overlay is used in order to compare different units, and to reclassify them to similar units for land suitability analysis to locate the best site.

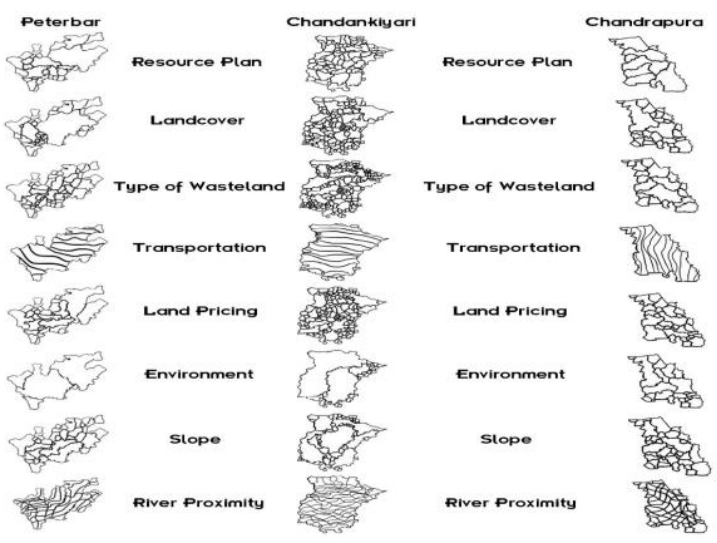

Figure 10 - Reclassified Map obtained for various spatial layers and predefined criterias

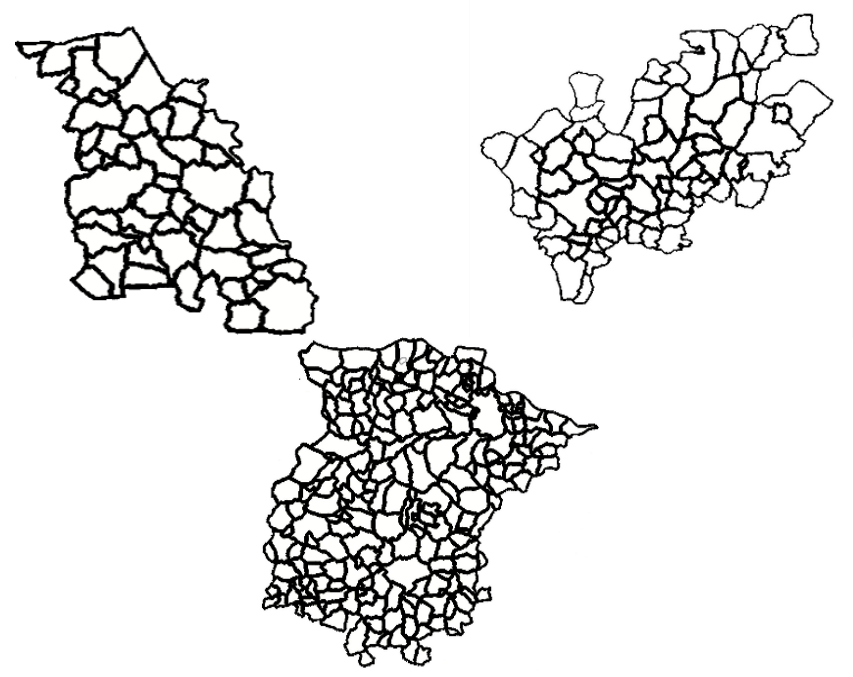

Figure 11 -Final Raster Criteria Maps

\section{WEIGHTED OVERLAY METHOD}

Overlay method is a GIS operation which uses the superimposing of multiple data sets, one over another layer and is helpful in identifying the relationship amongst the various attributes. A resultant new layer is created that combines the geometry and the attributes of all the input layers. The resultant sets of data are usually assigned with numerical values. These values then are mathematically merged together to create a new set of values for a single output layer

Overlay is a GIS operation that superimposes multiple data sets (representing different themes) together for the purpose of identifying relationships between them. An overlay creates a composite map by combining the geometry and attributes of the input data sets. Tools are available in most GIS software for overlaying both Vector or raster data.

Before the use of computers, a similar effect was developed by Ian McHarg and others by drawing maps of the same area at the same scale on clear plastic and actually laying them on top of each other

Feature overlays from vector data are created when one vector layer (points, lines, or polygons) is merged with one or more other vector layers covering the same area with points, lines, and/or polygons. A resultant new layer is created that combines the geometry and the attributes of the input layers.

Raster overlay involves two or more different sets of data that derive from a common grid. The separate sets of data are usually given numerical values. These values then are mathematically merged together to create a new set of values for a single output layer

Table 4 - Weighted Overlay Table for criteria and their relative influence over each other

\begin{tabular}{|c|l|c|}
\hline RANK & \multicolumn{1}{|c|}{ CRITERIA } & $\begin{array}{c}\text { INFLUENCE } \\
(\%)\end{array}$ \\
\hline 1 & LAND PRICING & 26.3 \\
\hline 2 & PROXIMITY TO TRANSPORT & 20.5 \\
\hline 3 & AVAILABILITY OF RESOURCES & 12.8 \\
\hline 4 & LANDCOVER AND LANDUSE & 12.2 \\
\hline 5 & ENVIRONMENTAL ATTRIBUTES & 11.3 \\
\hline 6 & AVAILABILITY OF WASTELAND & 7.8 \\
\hline 7 & SLOPE, TERRAIN & 5.3 \\
\hline 8 & RIVER PROXIMITY & 3.8 \\
\hline
\end{tabular}

The Weighted Overlay tool applies one of the most used approaches for overlay analysis to solve multicriteria problems such as site selection and suitability models. In a weighted overlay analysis, each of the general overlay analysis steps is followed. As with all overlay analysis, in weighted overlay analysis, you must define the problem, break the model into sub-models, and identify the input layers.

\section{RESULTS AND DISCUSSIONS}

Land allocation for industries is a complex process as the analysis considers various parameters. The two different raster values cannot be added as the units are different for different parameters. All the parameters cannot be of equal importance. After normalising the data each parameter is referred with a numerical value. More the value assigned by weighted overlay method, more it is important for the site location. Since this study has undertaken a certain criteria approach for site allocation. Various suitability criteria map was generated based on calculations from primary survey. The suitability of each criteria was assumed based on inception of decision makers

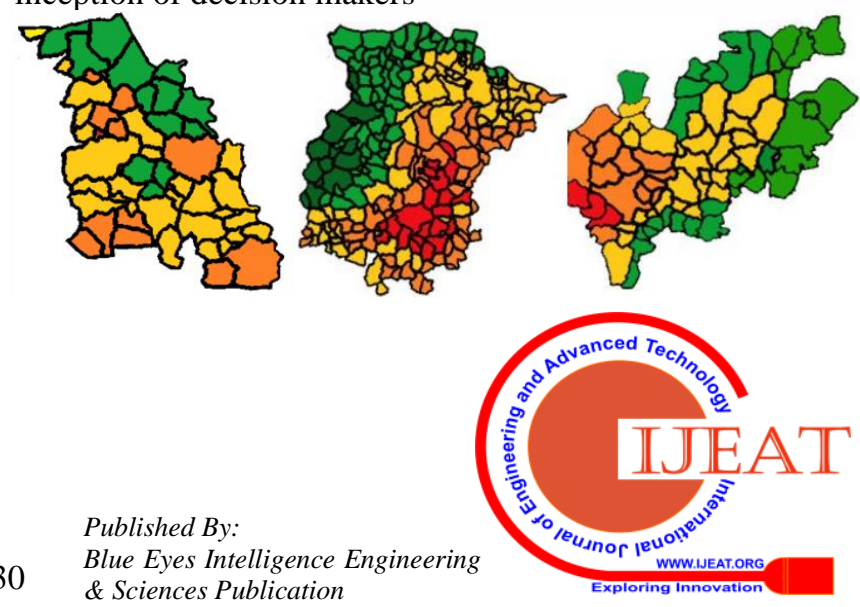


Identification of a New Industrial Area Based on a Macro-Level Analysis - a Case of Bokaro District, Jharkhand, India

\begin{tabular}{|c|c|c|c|}
\hline \multicolumn{5}{|c|}{ GOVT RESOURCES DEVELOPMENT PLAN (I) } \\
\hline WLC RESULTS $(\mathrm{S}=\Sigma$ WX) & INDEX (DISTANCE IN METERS) & SCALE & SUITABILITY SCORE (1-10) \\
\hline $0.20991-0.26239$ & $0-5000$ & HIGHLY SUITABLE & $8-10$ \\
\hline $0.15743-0.20991$ & $0-10000$ & MORE SUITABLE & $6-8$ \\
\hline $0.10495-0.15743$ & $0-15000$ & MODERATELY SUITABLE & $4-6$ \\
\hline $0.05247-0.10495$ & $0-20000$ & LESS SUITABLE & $2-4$ \\
\hline $0.05247-0.02623$ & $0-30000$ & LEAST SUITABLE & $1-2$ \\
\hline
\end{tabular}

\begin{tabular}{|c|c|c|c|}
\hline \multicolumn{4}{|c|}{ LAND PRICING (5) - GOVT RATES FOR INDUSTRIAL DEVELOPMENT (2017) } \\
\hline WLC RESULTS $(S=\Sigma W X)$ & NDEX (INR PER DECIMAL - 40.47 sq.m ) & SCALE & SUITABILITY SCORE (1-10) \\
\hline $0.45298-0.56623$ & $75000-85000$ & HIGHIY SUITABLE & $8-10$ \\
\hline $0.33973-0.45298$ & $85000-95000$ & MORE SUITABLE & 6.8 \\
\hline $0.22649-0.33973$ & $1050000-115000$ & MODERATELY SUITABLE & 46 \\
\hline $0.11324-0.22649$ & $125000-135000$ & LESS SUITABLE & 2.4 \\
\hline $0.05662-0.11324$ & $135000-145000$ & LEAST SUITABLE & 1.2 \\
\hline
\end{tabular}
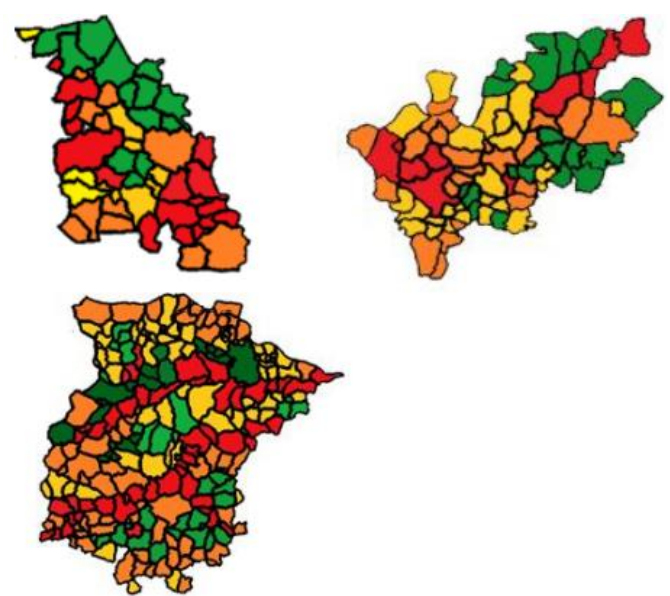

\begin{tabular}{|c|c|c|c|}
\hline \multicolumn{4}{|c|}{ LANDCOVER AND LANDUSE (2) } \\
\hline WLC RESULTS $(S=\Sigma \mathrm{WX})$ & INDEX & SCALE & SUITABILITY SCORE (1-10) \\
\hline $0.20888-0.26111$ & OPEN WASTELAND & HIGHLY SUITABLE & $8 \cdot 10$ \\
\hline $0.15666-0.20888$ & BUILDUP LAND (RURAL) & MORE SUITABLE & $6-8$ \\
\hline $0.10444-0.15666$ & AGRICULTURAL LAND/VEGETATED AREA & MODERATELY SUITABLE & 4.6 \\
\hline $0.05222-0.10444$ & TWO CROPCURRENT CROP LAND & LESS SUITABLE & $2 \cdot 4$ \\
\hline $0.026111-0.05222$ & TREE CLAD/BUILUTP AREAWATER BODIES & LEAST SUITABLE & 1.2 \\
\hline
\end{tabular}
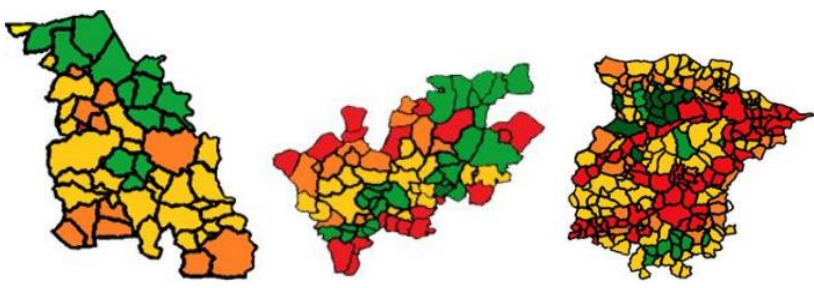

\begin{tabular}{|c|c|c|c|}
\hline \multicolumn{4}{|c|}{ TYPE OF WASTELAND (3) } \\
\hline WLC RESULTS $(S=\Sigma \mathrm{WX})$ & INDEX & SCALE & SUITABILITY SCORE $(1-10)$ \\
\hline $0.13336-0.16667$ & INDUSTRIAL WASTELAND & HIGHLY SUTTABLE & 8.10 \\
\hline $0.10002-0.13336$ & BARREN ROCKY/STONY WASTELAND & MORE SUTIABLE & $6-8$ \\
\hline $0.06668-0.10002$ & LAND WITH OPEN SCRUB & MODERATEIY SUTTABLE & 46 \\
\hline $0.03334-0.06668$ & LAND WITH DENSE SCRUB & LESS SUITABLE & 24 \\
\hline $0.01667-0.03334$ & PAST FALLOW LAND & LEAST SUTTABLE & 1.2 \\
\hline
\end{tabular}
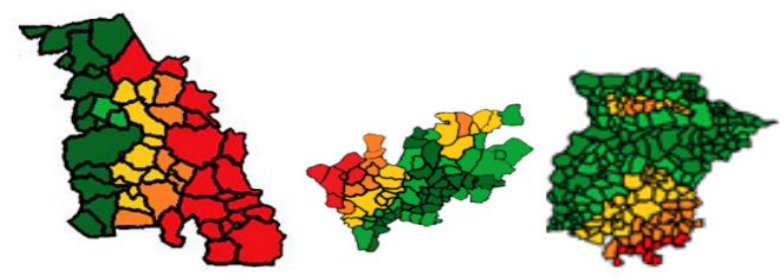

Figure 12

\begin{tabular}{|c|c|c|c|c|}
\hline \multicolumn{5}{|c|}{ PROXIMITY TO TRANSPORT CORRIDOR (4) - ROADSRAIL. } \\
\hline WLC RESULTS $(\mathrm{S}-\Sigma \mathrm{WX})$ & ROAD DISTANCE (m) & RAIL DISTANCE (m) & SCALE & SUITABILITY SCORE $(1-10)$ \\
\hline $0.35042-0.43803$ & 0.500 & 0.3000 & HIGHLY SUITABLE & $8-10$ \\
\hline $0.26281-0.35042$ & $0-6000$ & $0-2500$ & MORE SUITABLE & $6-8$ \\
\hline $0.17521-0.26281$ & 0.700 & $0-2000$ & MODERATELY SUTTABLE & $4-6$ \\
\hline $0.08766-0.17521$ & $0-800$ & $0-1500$ & LESS SUITABLE & 24 \\
\hline $0.04380-0.08766$ & $0-1000$ & 0.500 & LEAST SUITABLE & $1-2$ \\
\hline
\end{tabular}
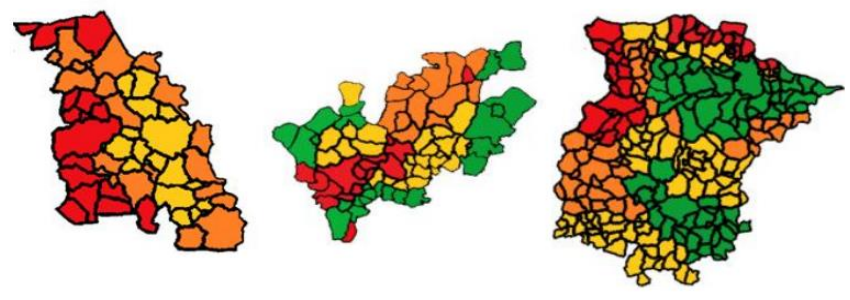
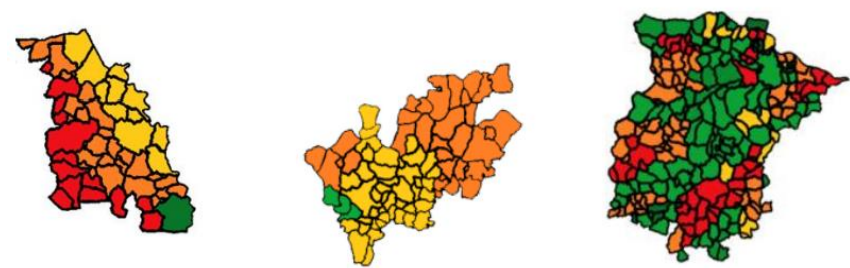

SLOPE, TOPOGRAPHY, TERRAIN (6)

\begin{tabular}{|c|c|c|c|}
\hline \multicolumn{5}{|c|}{ SLOPE, TOPOGRAPHY, TERRAIN $(6)$} \\
\hline WLC RESULTS $(\mathrm{S}=\Sigma$ WX) & INDEX (SLOPE CLASSES - DEGREE) & SCALE & SUTTABILITY SCORE (1-10) \\
\hline $0.09059-0.11324$ & 0.4 & HIGHIY SUITABLE & $8-10$ \\
\hline $0.06794-0.09059$ & $4-6$ & MORE SUITABLE & $6-8$ \\
\hline $0.04529-0.06794$ & $6-8$ & MODERATELY SUITABLE & $4-6$ \\
\hline $0.02264-0.04529$ & $8-10$ & LESS SUTTABLE & $2-4$ \\
\hline $0.01132-0.02264$ & $10-12$ & LEAST SUITABLE & $1-2$ \\
\hline
\end{tabular}

Figure 13
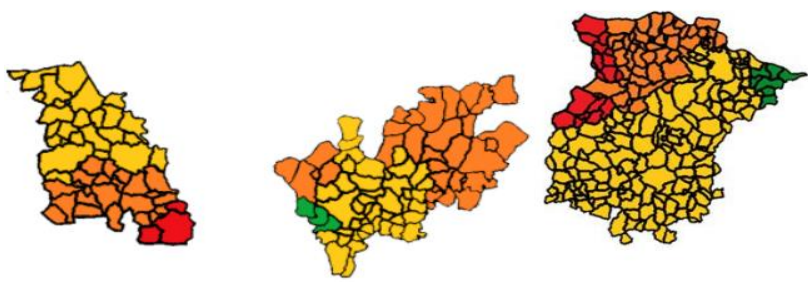

\begin{tabular}{|c|c|c|c|}
\hline \multicolumn{4}{|c|}{ ENVIRONMENTAL ATTRIBUTES (7) - ENVIRONMENTAL ALTAS - CPCB } \\
\hline WLC RESULTS $(S=\Sigma W X)$ & INDEX & SCALE & SUITABILTTY SCORE (1-10) \\
\hline $0.19144-0.23931$ & Z4WL (NO RISK ZONE) & HIGHLY SUTABBLE & 8.10 \\
\hline $0.14338-0.19144$ & Z4Wm (LOW RISK ZONE) & MORE SUITABLE & $6-8$ \\
\hline $0.09572-0.14358$ & Z4Wh (LOW RISK ZONE) & MODERATELY SUITABLE & $4-6$ \\
\hline $0.04786-0.09572$ & Z2Wh (MEDIUM RISK ZONE) & LESS SUITABLE & $2-4$ \\
\hline $0.02393-0.04786$ & ZIWh (HIGH RISK ZONE) & LEAST SUITABLE & $1-2$ \\
\hline
\end{tabular}
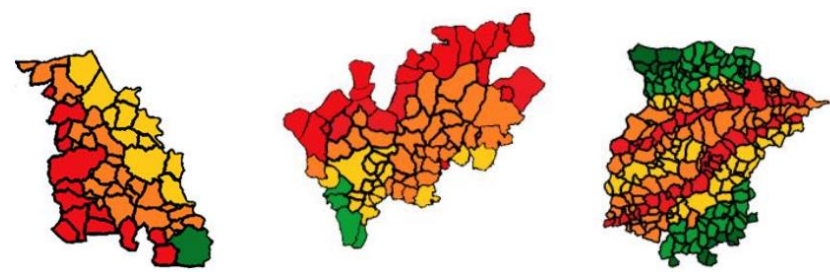

\begin{tabular}{|c|c|c|c|}
\hline \multicolumn{4}{|c|}{ RIVER PROXIMTY (8) } \\
\hline WLC RESULTS $(S=\Sigma W X)$ & RIVER DISTANCE (IN METERS) & SCALE & SUITABILITY SCORE $(1-10)$ \\
\hline $0.06495-0.08119$ & 0.1000 & HIGHLY SUITABLE & $8-10$ \\
\hline $0.04871-0.06495$ & 0.800 & MORE SUITABLE & $6-8$ \\
\hline $0.03247-0.04871$ & 0.600 & MODERATELY SUITABLE & 46 \\
\hline $0.01623-0.03247$ & $0-400$ & LESS SUITABLLE & 24 \\
\hline $0.00811-0.01623$ & 0.200 & LEAST SUITABLE & 1.2 \\
\hline
\end{tabular}

Figure 14

\section{A. SITE SUITABILITY INDICES}

The data assumed and generated through Spatial Analyst Tool in ArcGIS is to be overlayed to generate the final suitability map. The criteria maps symbolize the reclassified result of weighted criteria obtained through survey, this processed data acts as a measure of suitability in the criteria map. The overlay of all the eight criteria maps along with the assigned influence factor of each criteria will result in the final suitability map when processed with the help of weighted overlay tool. Site suitability is a decision support to spatial planning mechanism, hence best selected site should be recommended for industrial setup in the region.

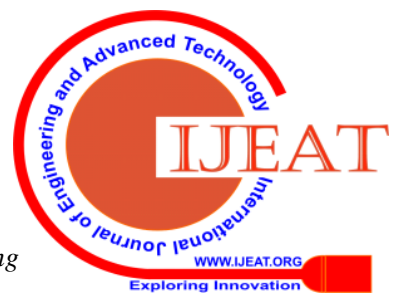


The present analysis concludes that there are many areas which are suitable for industrial siting but the best area can be determined by readings obtained for each area in the spatial analyst tool in GIS. Delineated region located in the Chandankiyari Region is the best site.
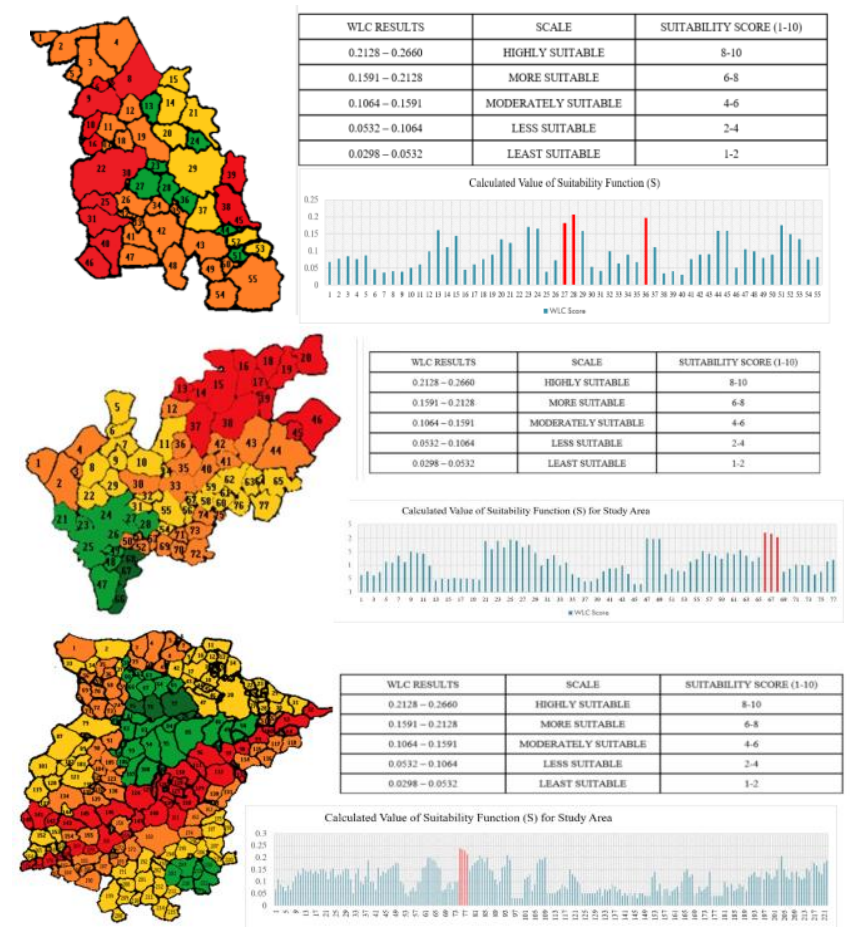

Figure 15 - Final Land Suitability Map for Siting of Industries (in Vector Form)

\section{CONCLUSION}

As industrial site location involves regional planning with spatial profile, it involves a huge set of feasible alternative solutions. The maximum number of alternatives is eliminated through various screening and elimination methods. The remaining alternative feasible sites are thus reduced to a minimum number, are further analyzed through weighted overlay method. This study uses GIS and MCDM for development of a suitability index, which finally identifies the most suitable site for the, subjective to the parameters, limitations and typology of the industries considered for this study. The methodology thus adopted in this study may find its applicability to a wider and different region having the similar parameters and socio-economic profile.

\section{REFERENCES}

1. Ahmed Mohamed Abushnaf, Lal Deepak, Pandey R.K, "Identification and Evaluation of New Industrial Zones in Giridih District using Remote Sensing \& GIS Techniques" International Journal of Engineering \& Technology Vol 1 Issue 5 Sep-Oct 2015

2. Arabsheibani Reza, Abedini Abbas, Sadat Yousef,, "Land Suitability assessment for locating industrial parks: a hybrid multi criteria decision making approach using GIS”, 2016

3. Department of Environment, Ministry of Natural Resources and Environment, a Guidelines for Siting and Zoning of Industry and Residential Areas for Malaysia Second Revised Edition, 2012

4. Eastman J.R, Toledano J, Kwaku Peter A., Weigen Jin, "Raster Procedures for Multi-Criteria/Multi-Objective Decisions", 1995

5. Effat H.A, Hegazy M.N, “Cartographic Modelling of Land Suitability for Industrial Development in the Egyptian Desert" International Journal of Sustainable Development Planning Vol 5 No.1,2010, Page 1

6. Eldrandaly Khalid, "A GEP-based spatial decision support system for multi-site land use allocation.”, 2010
7. Fernando G.M.T.S, Pinnawala Ven, "A GIS Model for Site Selection of Industrial Zones in Sri Lanka", 2015

8. Hazra P.B \& Aditi Acharya, "Geoinformatics for Industrial Siting - A Case Study of Puruliya District, West Bengal”, 2015

9. Jiang Jing, "Analysis of the Suitable and Low-Cost Sites for Industrial Land: Using Multi Criteria Evaluation: A Case of Panzhihua, China" School of Architecture and the Built Environment Royal Institute of Technology (KTH), 2007

10. Rikalovic Aleksander, Cosic Illja Piuri Vincenzo, Donida Labati, “A Comprehensive Method for Industrial Site Selection: The Macro-Location Analysis", 2015

11.Rikalovic Aleksander, Cosic Illja, “A Fuzzy Expert System for Industrial Location Factor Analysis" Acta Polytechnica Hungarica Vol 12 No.2, 2015

12.Sarapironme Sunya and Charungthanakij, "GIS Modeling for Industrial-Agriculture Landuse Planning: A Case Study of Phranakhon Si Aytthaya Province, Thailand" SUT SJST Vol 19 No.3 July-September 2013.

13.Velasquez Mark, Hester T. Patrick, "An Analysis of Multi-Criteria Decision-Making Methods" International Journal of Operations Research Vol.10 No.2 56-66, 2013

\section{AUTHORS PROFILE}

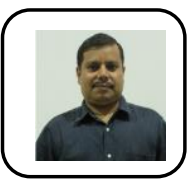

Bimal Chandra Roy is working as an Assistant Professor in the Department of Architecture, Birla Institute of Technology, Mesra, Ranchi, India and is an expert in the field of architecture and urban planning. He has more than eleven years of teaching and research experience. He graduated in architecture with a post-graduation in urban planning. He received his $\mathrm{PhD}$ from Birla Institute of Technology, Mesra, Ranchi, India. He has published numerous papers in reputed international journals in the field of sustainable architecture and urban planning.

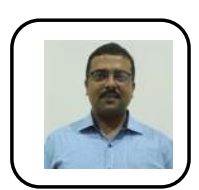

Satyaki Sarkar is working as an Associate Professor in the Department of Architecture, Birla Institute of technology, Mesra, Ranchi, India and is an expert in the field of industrial and urban planning. He has more than fifteen years of teaching and research experience. He completed his post graduation in city planning from IIT Kharagpur, India. He received his $\mathrm{PhD}$ from Jadavpur

University, India.

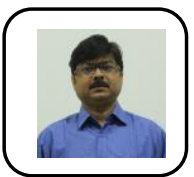

Rajan Chandra Sinha is currently working as an Assistant Professor in the Department of Architecture, Birla Institute of Technology, Mesra, Ranchi, India. He graduated in Architecture with a Post-Graduation in Urban Planning He received his $\mathrm{PhD}$ degree from Birla Institute of Technology, Mesra, India. He has more than 11 years of teaching and research experience. His research interest and publications are focused on varied housing issues, urban planning, sustainable architecture, construction management and disaster management planning techniques.

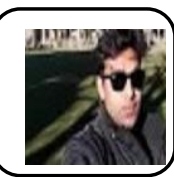

Indraneel Srivastava is working as Urban Planner in Heavy Engineering Corporation, Ranchi, India. He completed his post-graduation in urban planning from BIT Mesra, Ranchi, India. 